\title{
ОБНОВЛЕНИЕ ФОРМ, МЕТОДОВ И ИНСТРУМЕНТОВ УПРАВЛЕНЧЕСКОЙ ДЕЯТЕЛЬНОСТИ В СИСТЕМЕ ПУБЛИЧНОГО УПРАВЛЕНИЯ: ОСОБЕННОСТИ И НАПРАВЛЕНИЯ ПРАВОВОГО РЕГУЛИРОВАНИЯ
}

\author{
(c) 2020 Щукина Татьяна Владимировна \\ доктор юридических наук, доцент, ведущий научный сотрудник \\ Институт государства и права Российской академии наук, Россия, Москва
}

Предметом настоящей статьи выступает исследование новых направлений, форм и методов реализации публичного управления на современном этапе; рассмотрение правового регулирования современного публичного управления. Тема статьи отражает вопросы трансформации современной системы государственного управления с точки зрения формирования инновационной инфраструктуры стратегического развития в Российской Федерации. Целью настоящей статьи являются выявление на современном этапе трендов развития публичного управления, места и роли государства в этом процессе. Методологию данной работы составили сравнительный, формально-юридический, аналитический методы. Результаты работы - это формулирование особенностей правового регулирования стратегического развития Российской Федерации и системы современного публичного управления. Область применения результатов работы включает в себя систему публичного управления.

Ключевые слова: публичное управление, формы и методы публичного управления.

Трансформация системы публичного управления в Российской Федерации коснулась всех ее элементов и обусловила значительное изменение сущности правового регулирования. Меняется жесткая парадигма государственного управления, сформулированная исследователями административного права в конце XX века, создаются новые параметры системы российского публичного управления, основанные на общих драйверах преобразования управления, признанных всеми государствами в мире [1].

Происходит «перезагрузка» логики структурных связей, вертикальных отношений власти и подчинения в управлении, внедряется командный тип управления, значительно расширяется круг объектов, субъектов и функций публичного управления; преобразуются методы, формы и инструменты управления; подвергается преобразованиям нормативно-правовая основа управления; совершенствуются партнерские отношения государства и общества, формируя тем самым новое явление - общественные сети. Публичное управление становится гибким и адаптируемым к нестабильным условиям современного развития, способным функционировать в условиях ограничения ресурсов.

Выбор автором термина «публичное управление» не случаен и связан со следующими при- чинами:

1) формированием единой системы стратегического управления, включающей в себя множество участников стратегического планирования, задействованных в целеполагании, прогнозировании, планировании и программировании социально-экономического развития государства. Это - высшие должностные лица, органы государственной власти, государственные учреждения и органы местного самоуправления. Кроме того, система стратегического планирования объединяет и координирует действия ее участников с помощью ряда взаимоувязанных документов стратегического планирования, целей, задач и результатов социально-экономического развития страны, единого комплекса стратегических мероприятий на всех уровнях власти;

2) модернизацией роли органов местного самоуправления в системе государственного и муниципального управления. В настоящее время органы местного самоуправления (представительный и исполнительно - распорядительный органы местного самоуправления) встроены в систему формируемого стратегического управления. Это подтверждается реализацией механизма национального проектирования, Стратегии пространственного развития, национальных 
целей развития Российской Федерации. Например, в качестве рекомендаций по организации разработки и реализации национальных проектов в субъектах Российской Федерации предлагается закрепление в субъекте Российской Федерации персональной ответственности за выполнение мероприятий региональных проектов, в том числе в органах местного [2] самоуправления. Развивающаяся система стратегического планирования охватывает не только уровень Российской Федерации, но и уровни субъектов Российской Федерации и муниципальных образований, обеспечивая единство достижения целей и приоритетов социальноэкономического развития и национальной безопасности Российской Федерации [3]. Муниципальные образования разрабатывают стратегию и прогноз социально-экономического развития муниципального образования, реализуют муниципальные программы, принимают участие в национальных проектах, используют методы проектного управления в своей деятельности. С точки зрения правового регулирования местного самоуправления, учитывающего конституционный принцип его самостоятельности, не позволяет объединить (встроить) органы местного самоуправления в систему государственного управления. Опираясь на современное состояние экономического развития Российской Федерации и его нормативно-правового сопровождения, наблюдается прочная имплементация участников местного самоуправления в систему публичного управления;

3) появлением новых действующих участников публичного управления с особым правовым статусом и компетенцией, направленной на реализацию публичного интереса по достижению стратегических, национальных задач государства. Их функционирование изменяет облик государственного и муниципального управления, а также формы и принципы построения взаимоотношений, координации действий между органами власти и структурами общества. K ним следует отнести: промышленные кластеры, инвестиционные кластеры, государственные корпорации, моногорода, макрорегионы, социально ориентированные некоммерческие организации и другие. Некоторые их них (например, промышленные кластеры) не обладают устойчивым, целостным правовым статусом. Для создания кластера достаточно инициативы нескольких промышленных предприятий и подписания гражданско-правового соглашения о его создании, но значение результатов деятельности этого участника велико. Оно заключается в разработке и продвижении на рынке импортозамещающей промышленной продукции (станкостроение, инновационные технологии в нефтедобыче, переработке сырья и т.п.);

4) формированием новых функций публичного управления, включая функции органов исполнительной власти, применением новых методов публичного управления и новых экономико-коммуникационных инструментов управления. Среди новых методов, применяемых в настоящее время в системе публичного управления, следует выделить: а) обновленный по своему содержанию метод партнерства (кооперации), б) метод проектного управления, в) метод Lean-технологий (бережливое производство), г) методы комплаенса (антимонопольный, антикоррупционный); д) оценка регулирующего воздействия; е) сетецентрические методы; ж) методы оценки (оценка регулирующего воздействия, рейтинги и т.п.). Цифровые технологии выступают новыми экономикокоммуникационными инструментами в системе публичного управления, изменяющими действующие формы и методы государственного и муниципального управления. Появляется цифровое, электронное государственное управление, которое обновляет сущность функции автоматизации управления, превращая ее в функцию цифровизации управления.

5) объекты и формы публичного управления. Это - в классическом понимании человек, коллективы людей, объединения организаций и иные социально-экономические общности. Изменение подходов к публичному управлению, формирование новых политико-социальных и экономических отношений определило возникновение новых объектов публичного управления - общественных сетей. Общественные и гуманитарные науки под «сетью» подразумевают социальную структуру, состоящую из узлов, которыми являются люди, организации и связи (взаимоотношения) между ними [4].

6) Методы публичного управления. Происходит постепенное расширение методологии публичного управления. Она пополняется за счет экономических, политологических методов, методов логистики. Кроме того, более широкое использование принципов и методов частно-правового регулирования (автономность воли сторон, свобода заключения договора и т.п.) определяет специфику статуса 
частно-публичного субъекта управления, создание новых форм и видов публичного управления. Большое значение придается в настоящее время методу проектного управления в системе публичного управления. По мнению ученых, управление проектами в органах государственной власти отличается от управления проектами в предпринимательской деятельности. Оно носит жесткий правовой характер, подотчетно вышестоящим органам исполнительной власти, финансируется за счет бюджетных ресурсов; подлежит общественному контролю и публичной отчетности. И относительно содержания самих проектов, то они масштабны, многогранны, направлены на достижение социального эффекта прежде, чем будет получена выгода от привлечения в него инвестиций. Цели государственных проектов амбициозны и носят долгосрочный характер [5].

Оценить роль этих признаков в практической работе органов исполнительной власти сложно. Однозначного ответа на подобный вопрос: «эффективно или не эффективно», не будет. В настоящее время государство инициирует проекты, предлагает концепции решения стратегических задач развития РФ и социальноэкономических проблем. Оно приглашает к их разрешению структуры государственного сектора, частный бизнес и организации общественного сектора, объединяя всех в целях изыскания внутренних ресурсов в достижении поставленных целей. Обеспечивает на 90\% финансирование проектов из федерального бюджета. В этом случае, необходим жесткий контроль за расходованием бюджетных ресурсов, как со стороны государства, так и со стороны общества. Общественные институты контролируют в большей степени реализацию проектов, потому что в первую очередь граждане получают услуги, возможность использования объектов социальной инфраструктуры, информационных площадок и технологий. Без этих инструментов управление государственными проектами бессмысленно.

Инициатива государства по реализации проектов является временным явлением в системе публичного управления, рассчитанного на зарождение самостоятельности и активных решений со стороны бизнеса. В идеальной конструкции публичного управления представители бизнес-сообщества первыми проявляют инициативу по решению социально-экономических вопросов, начиная от строительства дорог и завершая возведением стадионов, больниц, мостов и иных значимых объектов. Государство, в свою очередь, одобряет эти инициативы и при их целесообразности и социальной важности гарантирует реализацию проекта. Это могут быть различного рода гарантии: финансовая, инфраструктурная, информационная, технологическая, правовая и иная поддержка. В условиях санкционных ограничений бизнес, особенно субъекты среднего и малого предпринимательства, не готов самостоятельно выдвигать крупные инициативы и оплачивать их, даже при условии предоставления последующих выплат в возмещение затраченных средств. Подобная ситуация требует государственной поддержки и гарантирования проектов до появления инновационных технологий и креативных идей по формированию собственных инвестиционных ресурсов у предпринимателей, достаточных для разработки и выполнения проектов.

Совместные действия по достижению конкретных результатов проекта в дальнейшем позволят привлечь и иностранные инвестиции, и инвестиции российского бизнеса. И в большей степени за счет кооперации предпринимателей, публичных юридических лиц, органов государственной власти удастся достичь запланированных эффектов. В любом случае прохождение этого этапа развития экономики и публичного управления будет сопровождаться неудачами, ошибками, победами и инновационными решениями.

Безусловно, существуют шероховатости современного процесса управления проектами. Выявляется несоответствие между реализацией направлений государственной политики в форме проектов и программ с одной стороны и отсутствие методологического и организационного обеспечения управления данными проектами [6] с другой стороны. Просматриваются проблемы технологической и информационной площадки управления проектами в органах исполнительной власти, но есть уже и положительные практики подобной деятельности (образовательные центры по инклюзивному образованию, строительство больниц и т.п.). Выделены лидеры проектного управления - субъекты РФ: Ленинградская область, Ханты-Мансийский автономный округ - Югра, Белгородская область, Свердловская область и др. В Приморском крае, например, действует Проектный кодекс, утв. постановлением администрации Приморского 
края от 25.04.2016 № 160-па, а государственные служащие, занимающиеся проектным управлением, мотивированы.

Также распространены в публичном управлении методы оценки. Оценка тех или иных процессов в публичном управлении стала неотъемлемой частью содержания управленческой деятельности и одной из главных функций публичного управления.

7) Применение цифровых технологий в системе публичного управления. Это серьезно изменяет внешнее выражение форм управленческой деятельности органов исполнительной власти. Для обновленных форм управленческой деятельности будут характерны такие черты, как простота и мобильность. Помимо внешнего изменения форм управленческой деятельности цифровые технологии трансформируют и сущность принятия управленческого решения, включая его правовое оформление; структуру взаимных управленческих связей внутри государственного аппарата. Единоначалие сменяется коллективным принципом управления, оно децентрализуется, и из моно - центра управления превращается в поли-структурные связи управления. Публичное управление становится полицентричным.

Цифровые технологии и новые подходы к осуществлению публичного управления формируют новые функции публичного управления. Одной из новых функций является цифровизация публичного управления, что требует реализации защиты цифровых прав, использования электронной цифровой подписи, электронных площадок для предоставления государственных услуг и т.п. Все вышеуказанное нуждается в добротной нормативной правовой основе, гармонично сочетающей в себе реализацию публичного и частного интересов.

8) изменение системы и структуры законодательства. Публичное управление объединяет все уровни и виды исполнительных органов государственной власти и местного самоуправления, социальные группы (добровольчество, социально - ориентированные некоммерческие организации, субъектов различных видов кооперации, промышленности и других отраслей управления и экономики), общественные группы (общественные советы и т.п.) в целях решения стратегических задач развития Российской Федерации. В связи с чем, сформировался массив нормативных актов, регулирующих публичное управление в РФ. Он содержит в себе пра- вовые нормы различных отраслей публичного права и даже частного права (государственночастное партнерство в части заключения концессионных соглашений и др.). И данное правовое образование нормативных правовых актов требует детального исследования, классификации, структуризации и оценки.

Вся система нормативных правовых актов исполнительных органов государственной власти и местного самоуправления строится в единой вертикали и на общих началах правового регулирования, которое определяется Президентом РФ и федеральными органами государственной власти. Основополагающие нормативные правовые акты Президента и федеральных органов исполнительной власти закрепляют обязательные рекомендации к разработке и утверждению на региональном и муниципальном уровнях подобных нормативных правовых актов. Устанавливая тем самым единые принципы и характеристики государственного и муниципального управления, отражающиеся в системе законодательства о публичном управлении.

Система законодательства строится на современных международных драйверах развития управления и конституционных драйверах публичного управления, основанных на конституционной модели компетенции власти. Новое содержание нормативных правовых актов, базирующееся на административном регламентировании, стандартизации, стратегическом планировании, прогнозировании и программировании. Новая идеология создания законодательства о публичном управлении, когда происходит аккумулирование различных идей (социальных, экономических, политических), а затем эта совокупность идей трансформируется в серию последующих нормативных правовых актов в области публичного управления. И накопление идей происходит, например, на электронной площадке (стратегия социальноэкономического развития Российской Федерации 2035). Законодательство становится гибким и «живым». Например, Морская доктрина, национальные проекты, некоторые стратегии не имеют формы нормативных правовых актов. По сути, эти правила превращаются в живое право. Такое правовое поведение органов исполнительной власти диктуется развитием экономической ситуации, которая развивается быстрее, чем разрабатываются нормативные правовые акты. 


\section{Библиографический список}

1. Преобразование нашего мира: Повестка дня в области устойчивого развития на период до 2030 года: Резолюция, принятая Генеральной Ассамблеей 25 сентября 2015 года. Режим доступа. URL: https://unctad.org/ meetings/ en/SessionalDocuments/ares70d1_ru.pdf

2. Методические указания по разработке национальных проектов (программ), утв. Правительством РФ 4 июня 2018 г. N 4072п-П6

3. о стратегическом планировании в Российской Федерации: федеральный закон от 28 июня 2014 г. N $172-Ф 3$ // Собр. законодательства Рос. Федерации. 2014. N 26 (часть I). Ст. 3378.

4. О стратегическом планировании в Российской Федерации: федеральный закон от 28 июня 2014 г. N $172-$ // Собр. законодательства Рос. Федерации. 2014. N 26 (часть I). Ст. 3378.

5. Васильев А.И., Прокофьев С.Е. Организация проектного управления в органах государственной власти // Государственное и муниципальное управление. 2016. № 4. С. 46.

6. Раменская Л.А. Особенности проектного управления в органах государственной власти на региональном уровне // Фундаментальные исследования. 2018. № 1. С. 111-115. 